\title{
PROFESIONALISME GURU SD / MI
}

\author{
Nursalim \\ Program Studi PGMI UIN Suska Riau \\ Kampus: Jalan HR. Soebrantas KM. 15 Tampan Pekanbaru, Riau \\ Email: nursalim@uin-suska.ac.id
}

\begin{abstract}
Abstrak:
Guru harus memiliki empat kompetensi dasar yaitu; kompetensi pedagogik, kompetensi kepribadian, kompetensi sosial dan kompetensi profesional. Kompetensi profesional guru Sekolah Dasar/Madrasah Ibtidaiyah yaitu: 1) Menguasai materi, struktur, konsep, dan pola pikir keilmuan yang mendukung mata pelajaran yang diampu, 2) menguasai standar kompetensi dan kompetensi dasar mata pelajaran/bidang pengembangan yang diampu, 3) mengembangkan materi membelajaran yang diampu secara kreatif, 4) mengembangkan keprofesionalan secara berkelanjutan dengan melakukan tindakan reflektif, 5) memanfaatkan teknologi informasi dan komunikasi untuk berkomunikasi dan mengembangkan diri. Profesionalisme guru dapat ditingkat. Upaya-uapaya yang dapat dilakukan dalam meningakatkan prafesionalisme guru yaitu: 1) membaca buku-buku tentang pendidikan, 2) membaca dan menulis karya ilmiah, 3) mengikuti berita aktual dari media pemberitaan, 4) mengikuti pelatihan, 5) mengikuti KKG, 6) melakukan Penelitian Tindakan Kelas (PTK), dan 6) berpartisipasi aktif dalam organisasi profesional.
\end{abstract}

\begin{abstract}
:
Teachers must have four basic competencies namely; pedagogical competence, personality com- petence, social competence and professional competence. Professional competence of teachers of Primary School / primary islamic school includes 1) Mastering the materials, structure, concept, and scientific mindset that support the subjects being taught, 2) mastering the competency standard and basic competency of the subjects being taught, 3) developing the material being taught creatively, 4) develop professionalism in sustainably by doing reflective actions, 5) utilizing information and communication technology to communicate and develop themselves. Teacher professionalism can be leveled. Efforts that can be done in improving teacher profesionalism are: 1) reading books about education, 2) reading and writing scientific papers, 3) following the actual news from news media, 4) joining training, 5) following Teacher Working Group, 6) conducting Classroom Action Research (CAR), and 6) participating actively in professional organizations.
\end{abstract}

Kata kunci:

Profesional, Guru, Kompetensi

PERADABAN manusia dari waktu ke waktu terus mengalami perubahan dan perkembangan. Hal ini disebabkan kerena perkembangan peradaban manusia dan teknologi yang diciptakan manusia. Perkembangan peradaban manusia menuntut para pendidik untuk mempu mengikuti perkembangan zaman tersebut agar pendidikan sebagai pilar pembangunan dapat menyesuaikan dan mengarahkan peserta didik ke arah yang tepat dan bersaing dalam kehidupan. 
Perkembangan zaman dan era globalisasi yang sangat pesat menuntut adanya peningkatan mutu pendidikan. Setiap sistem pendidikan harus mampu melakukan perubahan-perubahan ke arah perbaikan dan peningkatan mutu. Sistem pendidikan harus mampu memberdayakan berbagai komponen pendidikan yang mencakup program kegiatan pembelajaran, pendidik (guru), peserta didik, sarana dan prasarana pembelajaran, dana, lingkungan masyarakat, kepeminpinan kepala sekolah dan lainlain.

Eksistensi guru yang profesional dan berkompeten merupakan suatu keharusan yang tidak dapat ditawar-tawar lagi untuk memudahkan pencapaian tuntutan dan tujuan pembelajaran di skolah. Guru yang profesional akan mampu mencerminkan sosok keguruannya dengan wawasan yang luas dan memiliki sejumlah kompetensi yang menunjang tugasnya. Kompetensi yang harus dimiliki oleh seorang guru untuk mengaktualisasikan dirinya sebagai pendidik terangkum dalam empat kompetensi dasar seorang guru, seperti tercantum pada Lampiran Peraturan Menteri Pendidikan Nasional No. 16 Tahun 2007 yaitu: kompetensi pedagogik, kompetensi kepribadian, kompetensi sosial, dan kompetensi profesional. Keempat kompetensi guru tersebut menjadi tuntutan sebagai seorang guru mampu berkiprah di tengah-tengah perkembangan zaman.

Guru memegang peranan utama dalam pembangunan pendidikan, khususnya yang diselenggarakan secara formal di sekolah. Guru juga sangat menentukan keberhasilan peserta didik, terutama dalam kaitannya dengan proses belajar mengajar. Guru merupakan komponen yang paling berpengaruh terhadap terciptanya proses dan hasil pendidikan yang berkualitas. Oleh karena itu, upaya perbaikan apapun yang dilakukan untuk meningkatkan kualitas pendidikan tidak akan memberikan sumbangan yang signifikan tanpa didukung oleh guru yang profesional dan berkualitas. Dengan kata lain, perbaikan kualitas pendidikan harus berpangkal dari guru dan berujung pada guru pula. (Mulyasa, 2007: 5).

Dalam tulisan ini, penulis hanya akan membahas tentang kompetensi profesional, dan tidak bermaksud mengesampingkan ketiga kompetensi lainnya. Hal ini disebabkan kompetensi profesional lebih menitikberatkan kepada guru agar menguasai materi pembelajaran secara luas dan mendalam. Akan sangat tidak wajar jika seorang guru mengajarkan suatu ilmu pengetahuan yang tidak dikuasainya. Hal ini juga ada hubungannya dengan peran guru sebagai sumber belajar yang erat kaitannya dengan penguasaan materi. Guru sebagai sumber belajar harus mampu memberikan informasi dan pengetahuan kepada peserta didik.

\section{KAJIAN PUSTAKA}

\section{Guru Profesionalisme}

Pendidikan merupakan proses interaksi antara guru (pendidik) dengan peserta didik (siswa) untuk mencapai tujuan-tujuan pendidikan yang ditentukan. Pendidik, peserta didik, dan tujuan pendidikan merupakan komponen utama pendidikan. Men- 
didik adalah pekerjaan profesional. Oleh karena itu, guru sebagai pelaku utama pendidikan merupakan pendidik profesional. (Abuddin Nata, 2003: 135-136).

Guru merupakan salah satu dari komponen pendidikan yang sangat menentukan keberhasilan pembelajaran menuju pendidikan yang berkualitas. Semua komponen pendidikan tidak akan berpengaruh bagi terciptanya pengalaman belajar yang maksimal bagi murid bila tidak didukung oleh keberadaan guru yang profesional. Oleh karena itu, guru disebut sebagai unsur yang sangat menentukan keberhasilan belajar karena gurulah yang sangat dekat dengan murid dalam pendidikan sehari-hari di sekolah. Karena guru selalu disebut sebagai penentu keberhasilan peserta didik, maka guru harus memiliki kemampuan dan perilaku yang dapat memengaruhi peserta didik secara utuh dalam mengembangkan potensinya. Guru harus menguasai kompetensi dasar keguruan.

Departemen Pendidikan dan Kebudayaan Nasional telah menetapkan sepuluh kemampuan yang harus dimiliki sebagai guru profesional. Kesepuluh kemampuan profesional tersebut adalah: 1) Kemampuan merencanakan pengajaran, 2) kemampuan megelola proses belajar mengajar, 3) Kemampuan mengelola kelas, 4) Kemampuan menguasai landasan-landasan pendidikan, 5) kemampuan mengelola intraksi belajar mengajar, 6) Kemapuan menilai prestasi belajar siswa, 7) Kemampuan memberikan layanan bimbingan, 8) Kemampuan melakukan administrasi kelas dan sekolah, dan 9) Kemampuan memahami dan menafsirkan hasil penelitian guna keperluan pengajaran. (Depdiknas, 2006: 79).

Kompetensi profesional guru Sekolah Dasar/Madrasah Ibtidaiyah yaitu kompetensi yang harus dimiliki oleh guru pada tingkat SD/MI terhadap kemampuannya dalam melaksanakan tugas-tugasnya di sekolah yang mengacu pada Permendiknas Nomor 16 Tahun 2007 tentang Standar Kualifikasi Akademik dan Kompetensi Guru yang menjelaskan bahwa kompetensi profesional yaitu: 1) Menguasai materi, struktur, konsep, dan pola pikir keilmuan yang mendukung mata pelajaran yang diampu, 2) menguasai standar kompetensi dan kompetensi dasar mata pelajaran/bidang pengembangan yang diampu, 3) mengembangkan materi membelajaran yang diampu secara kreatif, 4) mengembangkan keprofesionalan secara berkelanjutan dengan melakukan tindakan reflektif, 5) memanfaatkan teknologi informasi dan komunikasi untuk berkomunikasi dan mengembangkan diri.

Guru adalah orang yang memberikan suatu ilmu atau kemampuan tertentu kepada seseorang atau sekelompok orang. Oleh karena itu, menjadi seorang guru harus memiliki keahlian khusus, pengetahuan, kemampuan, dan dituntut untuk dapat melaksanakan peranan-peranannya secara profesional yang dalam tugasnya tidak hanya mengajar, melatih tetapi juga mendidik. (Roqib dan Nurfuadi, 2009: 118).

Sebagai pendidik profesional, guru wajib memiliki kompetensi profesional keguruan dalam jenjang pendidikan apa pun. Kompetensi-kompetensi lainnya adalah kompetensi kepribadian, kompetensi pedagogik, dan kompetensi sosial.

Kompetensi profesional merupakan kemampuan guru dalam menguasai bidang ilmu pengetahuan, teknologi, seni, dan budaya. Kompetensi ini sekurang-ku- 
rangnya meliputi penguasaan materi pelajaran secara luas dan mendalam sesuai dengan standar isi program satuan pendidikan, mata pelajaran, dan kelompok mata pelajaran yang akan diampu, konsep dan metode disiplin keilmuan atau penguasaan terhadap struktur dan metodologi keilmuannya, teknologi atau seni yang relevan, yang secara konseptual menaungi atau koheren dengan program satuan pendidikan, mata pelajaran, atau kelompok mata pelajaran yang akan diampunya.

Kompetensi kepribadian merupakan kompetensi yang berkaitan dengan pribadi guru itu sendiri seperti tingkah laku atau perilaku guru itu sendiri. Pada kompetensi kepribadian, guru harus mampu mengarahkan dirinya menjadi guru yang mantap dan patut diteladani oleh peserta didik. Karena guru pada dasarnya adalah figur publik bagi siswanya.

Kompetensi pedagogik merupakan kemampuan guru yang berkaitan dengan pengelolaan pembelajaran peserta didik yang meliputi pemahaman terhadap peserta didik, perancangan dan pelaksanaan pembelajaran evaluasi hasil belajar, dan pengembangan peserta didik untuk mengaktualisasikan berbagai potensi yang dimilikinya.

Kompetensi sosial merupakan kemampuan guru untuk berkomunikasi dan berinteraksi secara efektif dan efisien dengan siswa, rekan kerja, orangtua, dan masyarakat sekitarnya, atasan maupun instansi yang manaunginya. Kompetensi ini sekurangkurangnya kompetensi untuk berkomunikasi baik secara lisan, tulis, maupun isyarat secara santun. Guru juga harus mampu menggunakan teknologi komunikasi dan informasi secara fungsional, bergaul secara efektif dengan peserta didik, dengan sesama pendidik, tenaga kependidikan, pimpinan satuan pendidikan, orang tua atau wali peserta didik. Bergaul secara santun dengan masyarakat sekitar dengan mengindahkan norma serta sistem nilai yang berlaku dan menerapkan prinsip persaudaraan sejati dan semangat kebersamaan.

\section{Upaya Meningkatkan Guru yang Profesionalisme}

Profesionalisme guru dapat ditingkatkan. Upaya-uapaya yang dapat dilakukan dalam meningakatkan prafesionalisme guru yaitu:

\section{Membaca Buku-buku tentang Pendidikan}

Seorang guru harus rajin membaca buku-buku pendidikan, karena dengan banyak membaca buku-buku pendidikan diharapkan guru dapat memiliki wawasan yang luas sehingga dapat membantu dalam penyampaian materi pembelajaran. Saat ini, telah banyak buku-buku pendidikan yang beredar dan dengan sangat mudah didapatkan, bahkan telah banyak pula guru-guru yang memiliki perpustakaan pribadi di rumah.

\section{Membaca dan Menulis Karya Ilmiah}

Udin Syaefudin Saud (2010: 108) mengatakan bahwa dengan membaca dan memahami isi jurnal atau makalah ilmiah lainnya dalam bidang pendidikan guru dapat mengembangkan profesionalismenya. Selain menambah wawasan dan pengetahuan, 
membaca dan menulis karya ilmiah juga dapat mengasah keterampilan guru dalam menuangkan ide-ide baru di bidang pendidikan.

\section{Mengikuti Berita Aktual dari Media Pemberitaan}

Guru yang profesional tidak akan mau tertinggal dengan informasi kekinian. Apalagi informasi mengenai dunia pendidikan. Selain dengan membaca buku-buku pendidikan guru, mengikuti berita dari berbagai media juga merupakan salah satu penunjang dalam upaya peningkatan kompetensi profesionalnya. Dengan mengikuti informasi terkini tentang pendidikan, guru akan dapat mengikuti perkembangan pendidikan dan dapat membuat sebuah inovasi baru yang lebih baik sesuai tuntutan pendidikan.

\section{Mengikuti Pelatihan}

Pelatihan merupakan salah satu upaya dalam meningkatkan kompetensi profesional guru, yang mana dalam pelatihan ini kemampuan guru diasah agar lebih baik. Ermita (2009: 25), menyebutkan bahwa pelatihan yang perlu diikuti dalam meningkatkan kemampuan profesional adalah pelatihan yang berhubungan dengan pelaksanaan tugas guru terutama sekali dalam pelaksanaan pembelajaran, sehingga setelah mengikuti pelatihan tersebut diharapkan guru memiliki pengalaman, keterampilan, dan pengetahuan baru tentang berbagai permasalahan pelaksanaan tugas guru, baik yang berhubungan dengan penguasaan materi pelajaran, penguasaan metode, kendala-kendala yang dihadapi dalam pelaksanaan pembelajaran termasuk upaya penanggulangannya, dan permasalahan yang berhubungan dengan pelaksanaan evaluasi maupun penilaian hasil pembelajaran para siswa.

Pelatihan yang efektif akan berdampak pada mutu output para peserta didik. Bukan saja pelatihan teknis mengajar, melainkan juga pelatihan pendidikan tentang tata kelola sekolah, kurikulum, dan manajemen kelas.

\section{Mengikuti KKG}

Kelompok Kerja Guru (KKG) merupakan tempat untuk mempertemukan guruguru dalam mengembangkan kompetensi profesionalnya. Depdikbud (1994/1995, h. 66) salah satu teknik dalam pembinaan/peningkatan kemampuan profesional guru adalah melalui kelompok kerja guru (KKG). Adapun yang dimaksud dengan Kelompok Kerja Guru (KKG) adalah Kelompok Kerja Guru (KKG) adalah wadah profesionalisme guru yang bersifat aktif, kompak dan akrab dalam membahas berbagai masalah profesional keguruan dengan prinsip dari guru oleh guru dan untuk guru dalam rangka pelaksanaan tugas". Depdikbud (1995: 3)

Tujuan umum dari KKG ini adalah untuk meningkatkan kompetensi (kemampuan) profesional guru dalam melaksanakan tugas mengajar di sekolah. Depdikbud $(1995,3)$ menyatakan bahwa tujuan kelompok kerja guru adalah meningkatkan kualitas sumber daya tenaga pendidikan yang tersedia, sehingga para guru dapat meningkatkan kualitas pendidikan itu sendiri dan pada gilirannya merupakan kualitas prestasi belajar dan output sekolah semakin bermutu. 


\section{Melakukan Penelitian Tindakan Kelas (PTK)}

Penelitian Tindakan Kelas (PTK) adalah suatu penelitian yang bersifat reflektif yang dilakukan oleh guru dalam rangka meningkatkan kompetensi profesionalnya. Penelitian Tindakan Kelas (PTK) dikatakan cukup efektif karena dapat dilakukan tanpa harus meninggalkan tugas mengajar.

Menurut E. Mulyasa (2005: 155) Penelitian Tindakan Kelas memiliki karakteristik sebagai berikut: (1) Masalah yang diangkat untuk dipecahkan dan kondisi yang diangkat untuk ditingkatkan harus berangkat dari praktek pembelajaran nyata di sekolah. (2) Guru dapat meminta bantuan orang lain untuk mengenal dan mengelaborasi masalah yang akan dijadikan topik penelitian.

Secara umum Penelitian Tindakan Kelas bertujuan untuk: 1) memperbaiki dan meningkatkan kondisi serta kualitas pembelajaran dikelas, 2) meningkatkan layanan profesinal dalam konteks pembelajaran di kelas, khususnya layanan kepada peserta didik, 3) memberikan kesempatan kepada guru untuk melakukan tindakan dalam pembelajaran yang direnanakan di kelas, dan 4) memberikan kesempatan kepada guru untuk melakukan pengkajian terhadap kegiatan pembelajaran yang dilakukannya.

Manfaat PTK adalah: 1) untuk mengembangkan dan melakukan inovasi pembelajaran, 2) merupakan upaya pengembangan kurikulum di tingkat kelas, dan 3) untuk meningkatkan profesionalisme guru, melalui upaya penelitian yang dilakukannya.

\section{Berpartisipasi Aktif dalam Organisasi Profesional}

Guru profesional mempunyai jiwa organisasi yang tinggi dan suka bekerja sama dalam tim (teamwork). Udin Syaefudin Saud (2010: 110) menyatakan bahwa ikut serta menjadi anggota organisasi juga akan meningkatkan profesionalisme seorang guru. Dalam organisasi profesional, kemampuan terkait profesi yang dimiliki akan terus dibina dan dikembangkan. Sejalan dengan pendapat Syaiful Sagala (2009: 27) yang mengatakan bahwa pembinaan yang diberikan dalam organisai adalah pembinaan yang berupa training profesi sebagai upaya memfasilitasi peningkatan kualitas anggota dan pengakuan masyarakat maupun pemerintah. Banyak organisasi yang memungkinkan untuk diikuti oleh guru, salah satunya adalah Persatuan Guru Republik Indonesia (PGRI). PGRI merupakan suatu wadah yang menampung aspirasi guru. PGRI juga melaksanakan training pengajaran bidang studi untuk semua jenis dan jenjang sekolah.

\section{Dampak Guru yang Prosesionalisme}

Kualitas pendidikan berada di tangan guru. Dari tangan guru akan melahirkan generasi terbaik atau generasi emas yang diidamkan bangsa. Masa depan sebuah bangsa ditentukan oleh generasi bangsa tersebut. Genarasi bangsa inilah nantinya yang akan memimpin, melaksanakan, dan membentuk negaranya pada masa yang akan datang. Sedangkan kualitas sebuah generasi sangat ditentukan oleh kualitas para gurunya. Guru yang profesional akan menghasilkan pendidikan yang sesuai dengan bakat, minat, dan karakteristik siswa. Di tangan guru yang profesional akan ter- 
bentuk siswa yang tangguh dalam menghadapi perkembangan zaman. Guru yang profesional akan mengajar secara tepat guna dan berdaya guna, karena guru profesional sangat memahami karakteristik siswa dan mampu mengembangkan karakter siswa menjadi insan yang berguna di masyarakat.

Dampak yang ditimbulkan dari guru yang profesional adalah: 1) peserta didik memperoleh jaminan pelayanan dan pengalaman belajar yang efektif, 2) pemenuhan standar dan mengembangkan kompetensi dirinya, sehingga mampu melaksanakan tugas utamanya secara efektif, sesuai dengan kebutuhan belajar peserta didik untuk menghadapi kehidupan di masa datang, 3) bagi sekolah/madrasah akan mampu memberikan pelayanan pendidikan yang lebih baik dan berkualitas, 4) orang tua/ masyarakat memperoleh jaminan bahwa anak mereka mendapatkan layanan pendidikan yang berkualitas dan pengalaman belajar yang efektif, dan 5) bagi pemerintah, dengan adanya guru yang profesional akan memberikan jaminan kepada masyarakat tentang layanan pendidikan yang berkualitas dan profesional.

\section{SIMPULAN}

Guru profesional dipandang dari segi tugas dan fungsinya adalah guru yang memahami karakteristik peserta didik; mampu mentransfer ilmu kepada peserta didik dengan menggunakan metode pembelajaran yang tepat; memanfaatkan teknologi secara tepat guna; menguasai metode dan teknologi; melaksanakan administrasi pembelajaran secara teratur; mampu berkomunikasi dengan peserta didik secara baik; menjalin hubungan dengan pakar-pakar pendidikan atau masyarakat umum; mengembangkan diri secara periodik melalui seminar-seminar, diklat, penataran; menjadi panutan bagi masyarakat dan terlibat dalamm kegiatan-kegiatan masyarakat; berkreasi dan mampu menuangkan ide-ide kreatif melalui tulisan, kegiatan nyata.

Profesionalisme guru dapat ditingkatkan. Upaya-uapaya yang dapat dilakukan dalam meningakatkan prafesionalisme guru yaitu: 1) membaca buku-buku tentang pendidikan, 2) membaca dan menulis karya ilmiah, 3) mengikuti berita aktual dari media pemberitaan, 4) mengikuti pelatihan, 5) mengikuti KKG, 6) melakukan Penelitian Tindakan Kelas (PTK), dan 6) berpartisipasi aktif dalam organisasi profesional.

\section{DAFTAR PUSTAKA}

Depdiknas. (2006). Model Pembelajaran Tematik Kelas Awal Dasar. Jakarta: Pusat Kurikulum Badan Penelitian dan Pengembangan.

Mulyasa, E. (2007). Standar Kompetensi dan Sertifikasi Guru. Bandung: Remaja Rosdakarya.

Nata, A. (2003). Paradigma Pendidikan Islam. Jakarta: PT. Grasindo.

Roqib, M., Nurfuadi. (2009). Kepribadian Guru. Purwokerto: STAIN Press.

Redaksi Sinar Grafika. (2008). Undang-Undang Guru dan Dosen. Jakarta: Sinar Grafika.

Sagala, S. (2009). Kemampuan Profesional Guru dan Tenaga Kependidikan. Bandung: Alfabeta.

Saud, U. S. (2010). Pengembangan Profesi Guru, Bandung: Alfabeta. 